\title{
EVALUATION OF YIELD AND RESISTANCE TO COTTON LEAF WORM FOR SOME NEW GENOTYPES OF SOYBEAN UNDER OLD LANDS AND NEWLY RECLAIMED LANDS CONDITIONS IN EL-BEHEIRA GOVERNORATE
}

\author{
F.A. Waly \\ Food Legumes Research Department, Field Crops Research Institute, ARC, Giza, Egypt
}

Received: Apr. 12 , 2021

Accepted: May. 5, 2021

\begin{abstract}
A field traial allowed in completely randomized design with three replications were conducted in the research farm of the agricultural research station of Etay Al-Baroud (old land) and the research farm of the Faculty of Agriculture, Damanhur University, in El-Bostan region, El-Beheira Governorate (newly reclaimed lands) during 2018 and 2019 seasons to evaluate the performance of twelve new genotypes of soybean compared with the three commercial varieties Giza 111, Giza 22 and Crawford. The resistance of genotypes to cotton leaf worm was estimated in the laboratory by raising a fourth instar larvae of cotton leaf worm and leaving them for feeding on the middle leaflet of the third upper trifoliate leaf of the plant for $\mathbf{2 4}$ hours, after that the areas that the insect fed on were measured as a percentage of the total area of the leaf (leaf area consumed). The resistance to cotton leaf worm in the field was estimated by vision according to the Smith and Brim 1979 method (defoliation \%). The results confirmed that mean square due to genotypes, locations and genotypes $x$ location were highly significant for all studied traits except the locations mean square for number of hairs under binocular field area and branches number/plant in the first season and genotypes $x$ location mean square of number of hairs under binocular field area, branches number /plant, maturity date and 100 -seed weight in both seasons as well as number of pods/plant in the second season. All tested genotypes significantly differ in their performances in all studied traits across the two locations and the four genotypes Line 3 , Line 105, Line 127 and Line 129 seemed to excellent genotypes for yield and resistance to cotton leaf worm across the two locations. The consumed leaf area caused by cotton leaf worm and oil percentage negatively associated with pubescence density while seed yield positively associated with pubescence density. Seed yield and oil percentage negatively associated with the defoliation value. In general, it can be said that the four soybean genotypes, Line 3, Line 105, Line 127 and Line 129 are promising genotypes that could be sowing in newly reclaimed lands to expand soybean cultivation in Egypt.
\end{abstract}

Key words: Soybean genotypes, New reclaimed land, Seed yield, Cotton leaf worm.

\section{INTRODUCTION}

Soybean [Glycine max (L.) Merrill] receive great interest in the developed world, such as the United States of America and China, because of their food and processing capabilities. Soybean seeds contain about $20 \%$ vegetable oil and $40 \%$ protein (Soybean meal. 2019). Soybean seeds used in many industries such as baby milk, poultry feed as well as many pharmaceutical and cosmetic industries. In Egypt, soybeans have not received the attention of the government due to the lack of many industries that depend mainly on soybeans (El-Agroudy et al., 2011). According to FAO estimates, the area of soybeans cultivated in Egypt did not exceed 14000 hectares in 2019, while the cultivated area worldwide in the same year was about 120.50 million 
hectares (FAOSTAT, 2019). The significant decrease in the area of soybeans grown in Egypt is due to many reasons, including that most of the soybean area is confined to the Nile Valley and Delta region, which causes great difficulty for soybeans in competing with maize and rice for the unit area. In addition, soybeans are not suitable for cultivation in sandy lands, especially with high salinity, due to the lack of varieties adapted to these conditions. As for biotic stresses, the cotton leafworm is considered one of the main obstacles in the spread of soybean cultivation in Egypt if it severely affected the crop, which led to the reluctance of many farmers to grow it. Environmental variables such as soil type often become a determinant of increased soybean area (Kuswantoro 2016) where the interaction between genotype and environment (GEI) caused difficulties in selecting superior lines (Kumar et al., 2014). But Optimization of such diverse environments can be achieved by the provision of high-yielding and stable adaptation soybean varieties (Jain and Kharkwal 2003). The development of new soybean cultivars involves the breeding of cultivars with high economic yield, tolerance to biotic and abiotic stresses, and stability in the target environments. . Also, there is a need for increasing soybean genetic diversity so that new cultivars suitable for high seed yield and resistance to cotton leafworm. To avoid genetic vulnerability associated with the narrowing of the genetic base of any crop, the GXE interactions of the germplasm are important (Kang, 1998). Therefore, the aim of this study was to evaluate some new genotypes of soybeans under the old lands in Etay AlBaroud and newly reclaimed lands in ElBustan region to determine the best genotypes for yield and resistance to cotton leaf worm that can be cultivated in newly reclaimed lands to expand soybean cultivation.

\section{MATERIALS AND METHODS}

The present study was conducted in two locations i.e. Etay El-Baroud agriculture research farm (OId land), agriculture research center (ETAY EL-BAROUD) and El-Bostan Experimental Farm (New recliamrd land), Faculty of Agriculture, Damanhour University, Egypt (L2) during 2018 and 2019 summer seasons to evaluate yield and resistence to cotton leaf worm of twelve new genotypes of soybean (Line 3, Line 26, line 89, line 105, line 113, line 117, line 127, line 153, line 154, line 181, line 191 and line 193) selected from crossing in the national breeding program compared with the three cheek cultivars Giza 111, Giza 22 and crawford. The name, pedigree and country of orgin of all tested genotypes are presented in Table 1. The exprimental soil physical and chemical properties of the two locations are presented in Table 2.

\section{Experimental Layout:}

During the two seasons all genotypes were sown on $25^{\text {th }}$ of May in two experiments designed in randomized complete block design with three replicates. Each plot consisted of 5 rows, each row was four meters long and $60 \mathrm{~cm}$ apart (plot size was $12 \mathrm{~m}^{2}$ ). Seeds were sown on both sides of the ridge with two seeds /hill with $20 \mathrm{~cm}$ hill spaces. The all other agricultural practices were done as recommended. No pesticide treatments were applied, the crop was provided with normal irrigation (Flood irrigation).

\section{Data recorded:}

In the two seasons 10 guarded plants were randomly taken at harvest to measure the following records plant height (cm), no. of branches/plant, no. of pods/plant and 100-seed weight (g). While, maturity date (days) was recorded as the number of days from seed sowing to $99 \%$ maturity on plot basis. Seed yield/plot $(\mathrm{kg})$ 
was measured as the total seed weight of was calculated by convert plot yield to fad. all plant in the plot, and seed yield/fad $(\mathbf{k g})$

Table 1. Name, pedigree and origin of all tested soybean genotypes.

\begin{tabular}{lcc}
\hline \multicolumn{1}{c}{ Genotypes } & Pedigree & Origin \\
\hline Line 3 & Crawford $\times$ L62-1686 & Egypt \\
\hline Line 26 & L62-1686 x Corsoy 79 & Egypt \\
\hline Line 89 & H5L21 x Giza 21 & Egypt \\
\hline Line 105 & Giza 35 x Lamar & Egypt \\
\hline Line 113 & H2 L20 x Major & Egypt \\
\hline Line 117 & D89-8940 x H2L20 & Egypt \\
\hline Line 127 & D89-8940 x Giza 83 & Egypt \\
\hline Line 129 & Giza 35 x Giza 83 & Egypt \\
\hline Line 153 & Giza 35 x H2L20 & Egypt \\
\hline Line 154 & Giza 35 x NC104 & Egypt \\
\hline Line 181 & Giza 22 $\times$ D89-8940 & Egypt \\
\hline Line 191 & Giza 83 x Line 127 & Egypt \\
\hline Line 193 & DR101 x Giza 111 & Egypt \\
\hline Crawford & Williams $\times$ Columbus & USA \\
\hline Giza 111 & Crawford x Celest & Egypt \\
\hline Giza 22 & Crawford x Forest & Egypt
\end{tabular}

Table 2. The exprimental soil physical and chemical properties of Etay El-Baroud and ElBostan locations during 2018 and 2019 seasons.

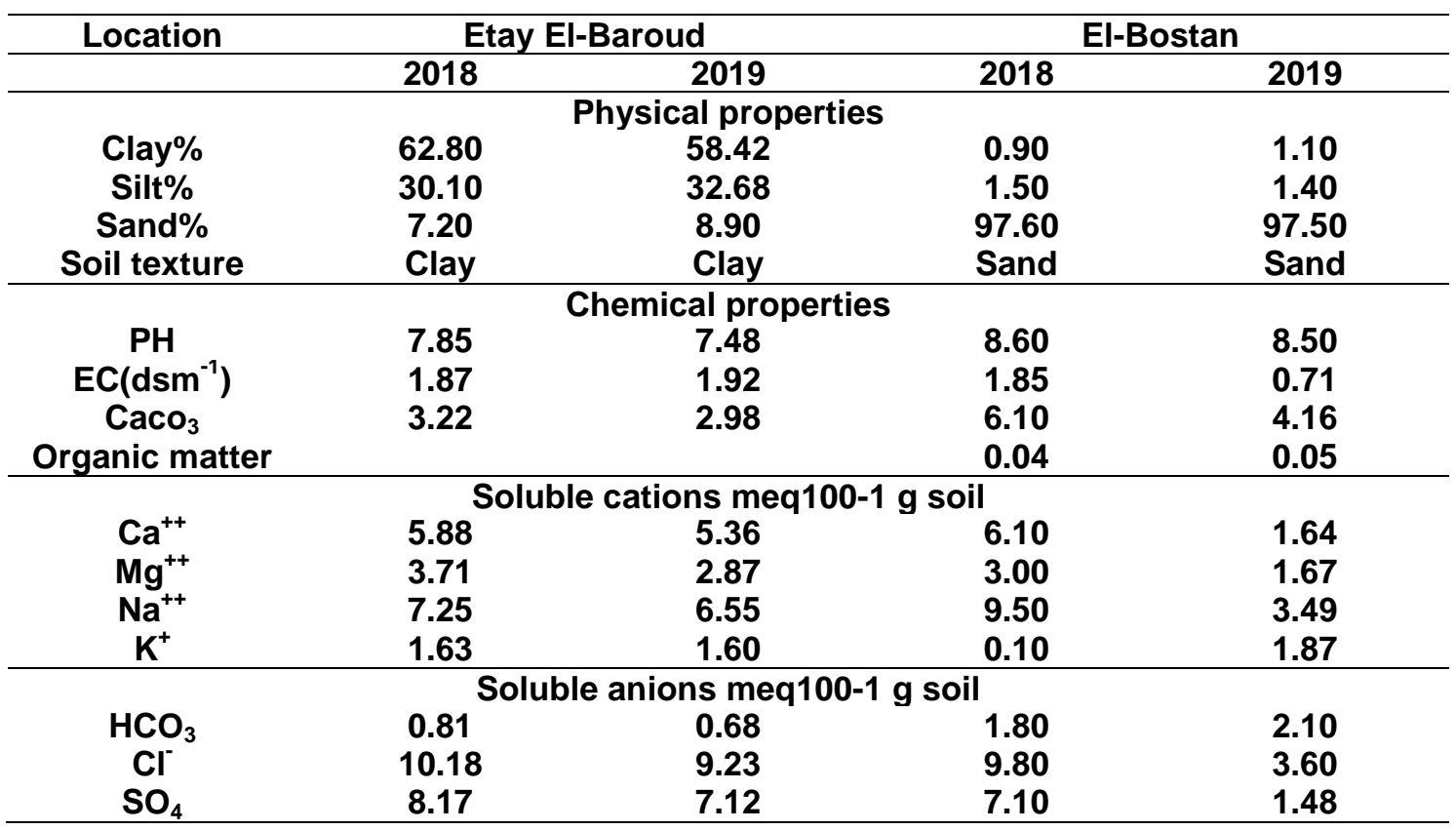

Resistance to cotton leaf worm [Spodoptera littoralis (Biosd)] was evaluated under the artificial infection in the laboratory and in the field under the natural infection using the following three criteria:

Hairiness: Number of hairs on the lower surface of the leaflet on the upper 
third trifoliate was counted under the binocular field $\left(0.5 \mathrm{~cm}^{2}\right)$.

The area of leaf tissue consumed (artificial infection): was estimated using the artificial infection in the laboratory where, one fourth instar larvae of Spodoptera littoralis was raising in the laboratory and placed in a glass container $1000 \mathrm{ml}$ capacity and was allowed to feed one fresh leaflet excised randomly from the upper third of each plant, including their petioles the area of leaf tissue consumed after 24 hours after that the areas that the insect fed on were measured as a percentage of the total area of the leaf (leaf area consumed). (Ademir et al., 2006).

Leaf feeding damage or foliage loss (defoliation \%): visual rating of percentage defoliation were recorded as the average of three time (every seven days) beginning two weeks after flowering, on each plant in the plot without insect control under the natural field infection, a stander diagram for estimating the percentage of defoliation was reported by Smith and Brim 1979 as shown in Fig. 1.

\section{Statistical analysis:}

Data were statistically analyzed, using the analysis of variance procedures for randomized complete block design and means were compared using the LSD test $(P<0.05)$, according to Gomez and Gomez (1984). Homogeneity of variance, in different locations, was tested following Bartlett's Test (Steel and Torrie 1980). Combined analyses of variance were performed among the different locations with homogeneous variance, as outlined by Cochran and Cox (1957).
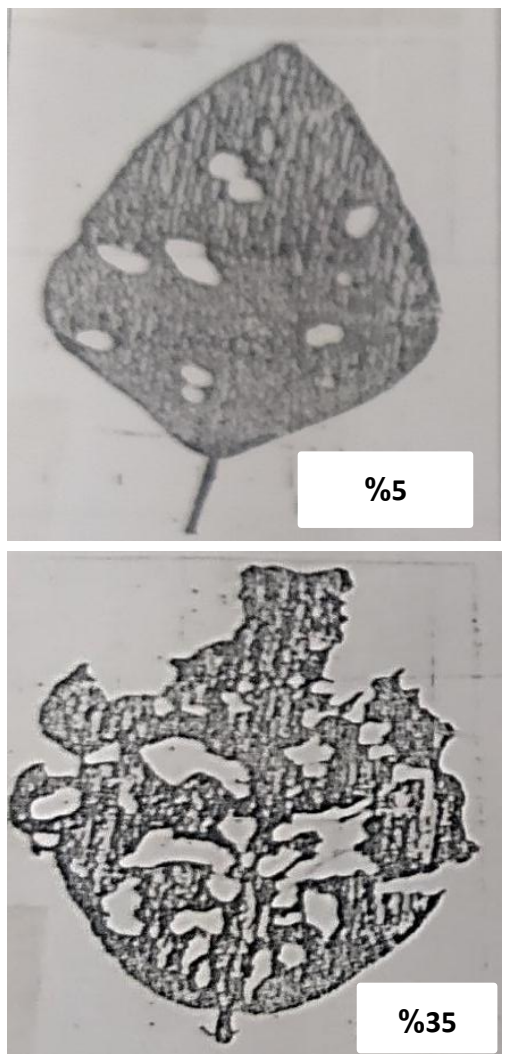
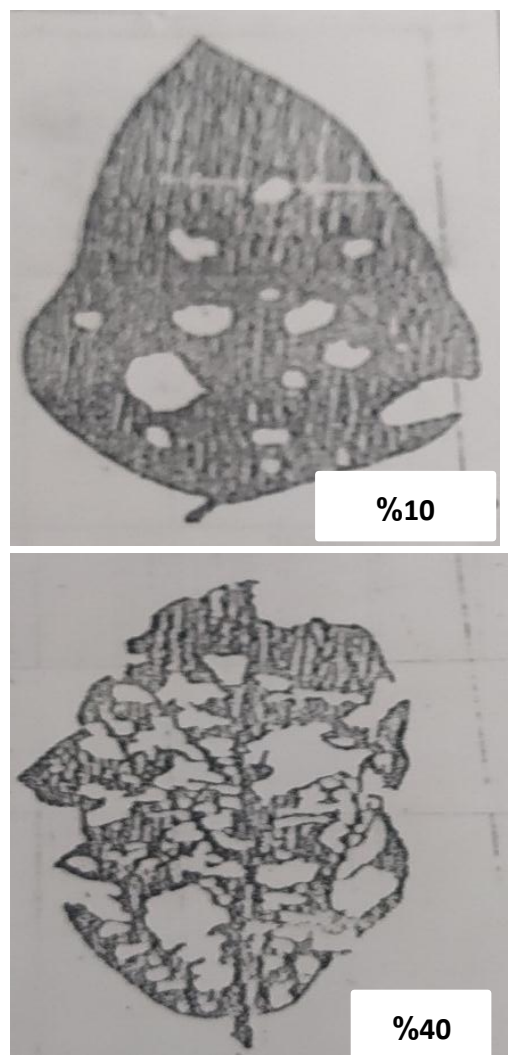

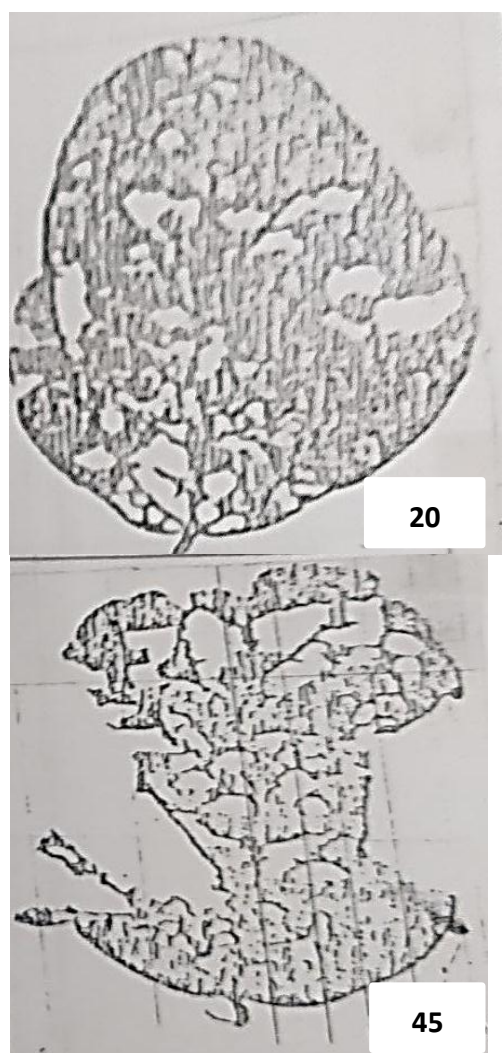

Fig. 1. Standard area diagram estimating the percentage of defoliation by Smith and Brim 1979. 


\section{RESULTS}

The homogeneity test between the two sowing locations showed the presence of homogeneity for the experimental error variance between the two locations in all studied traits except for the seed yield per plot and faddan in both seasons and number of pods/plant in the first season. Therefore, all genotypes performances were compared in each location and the combined analysis between the two locations was made in all traits Except for the seed yield per plot and faddan in both seasons and the number of pods in the first season, where the performance of genotypes was compared in each location individually.

\section{Analysis of variance}

\subsection{Resistance to cotton leaf worm.}

Genotypes mean squares for number of hairs under binocular field area (leaf Pubescence density), leaf area consumed and defoliation values in each locations and combined analysis are presented in Table 3. The results confirmed that mean square due locations, genotypes and locations $x$ genotypes were highly significant for all traits except for number hairs under binocular field area in locations in the first season and locations $x$ genotypes in the two seasons.

\subsection{Growth traits.}

For growth traits (maturity date, plant height and number of branches/plant) the obtained results in Table 4 revealed that mean square due locations, genotypes and locations $x$ genotypes were highly significant in for all growth traits except locations mean square for number of branches/plant in the first season and locations $x$ genotypes of maturity date and number of branches/plant in the two seasons.

\subsection{Seed yield and yield components traits.}

Regard to seed yield and yield components traits (number of pods/plant, 100-seed weight, seed yield/plot, seed yield/fad. and seed content of oil \%) the results in Table 5 indicated that mean square due genotypes were highly significant in both locations for number of pods/plant, 100-seed weight, seed yield/plot, seed yield/fad. and oil percentage in both seasons. Mean squares due to locations were highly significant for number of pods/plant in the second season and 100-seed weight seed content of oil in both seasons. On the other side, the interaction of locations $x$ genotypes were not significant for number of pods/plant in the second seasons and 100 -seed weight and oil percentage in both seasons.

\section{Mean performances.}

\subsection{Resistance to cotton leaf worm.}

Mean performances of all tested genotypes for number of hairs under binocular field area, leaf area consumed in the laboratory (artificial infection) and defoliation value in the open field (natural infection) in the two locations are presented in Table 6. For hairs number under binocular field area the results showed that the four genotypes Line 26, Line 105, Line 113 and Line 154 showed the highest number of hairs under binocular field area in both Etay ElBaroud and El-Bostan locations as well as the combined data in both seasons. In the contrast of this Crawford cv. and Line 193 showed the lowest number of hairs under binocular field area in both locations and the combined data in the two seasons of the study. 


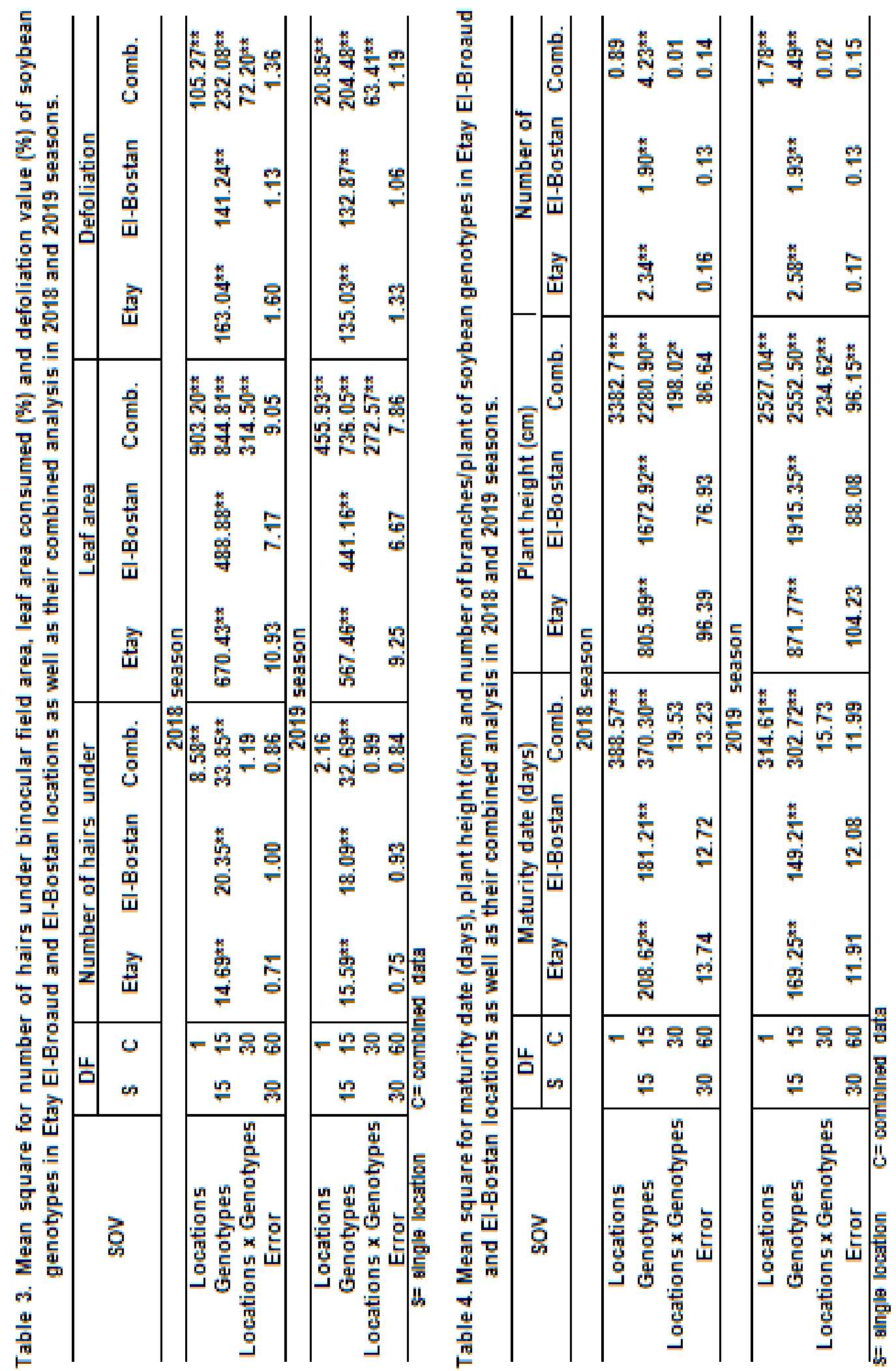




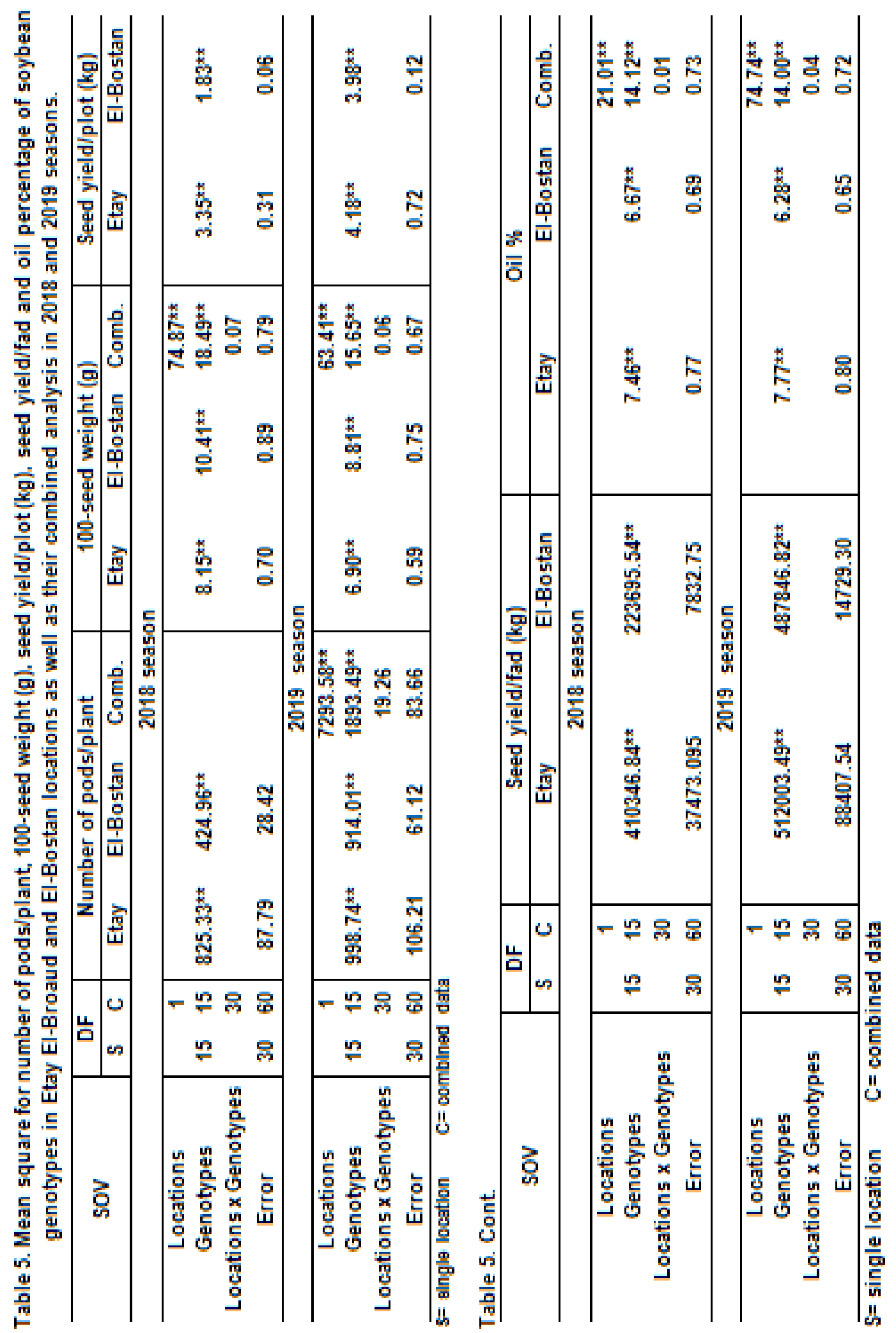




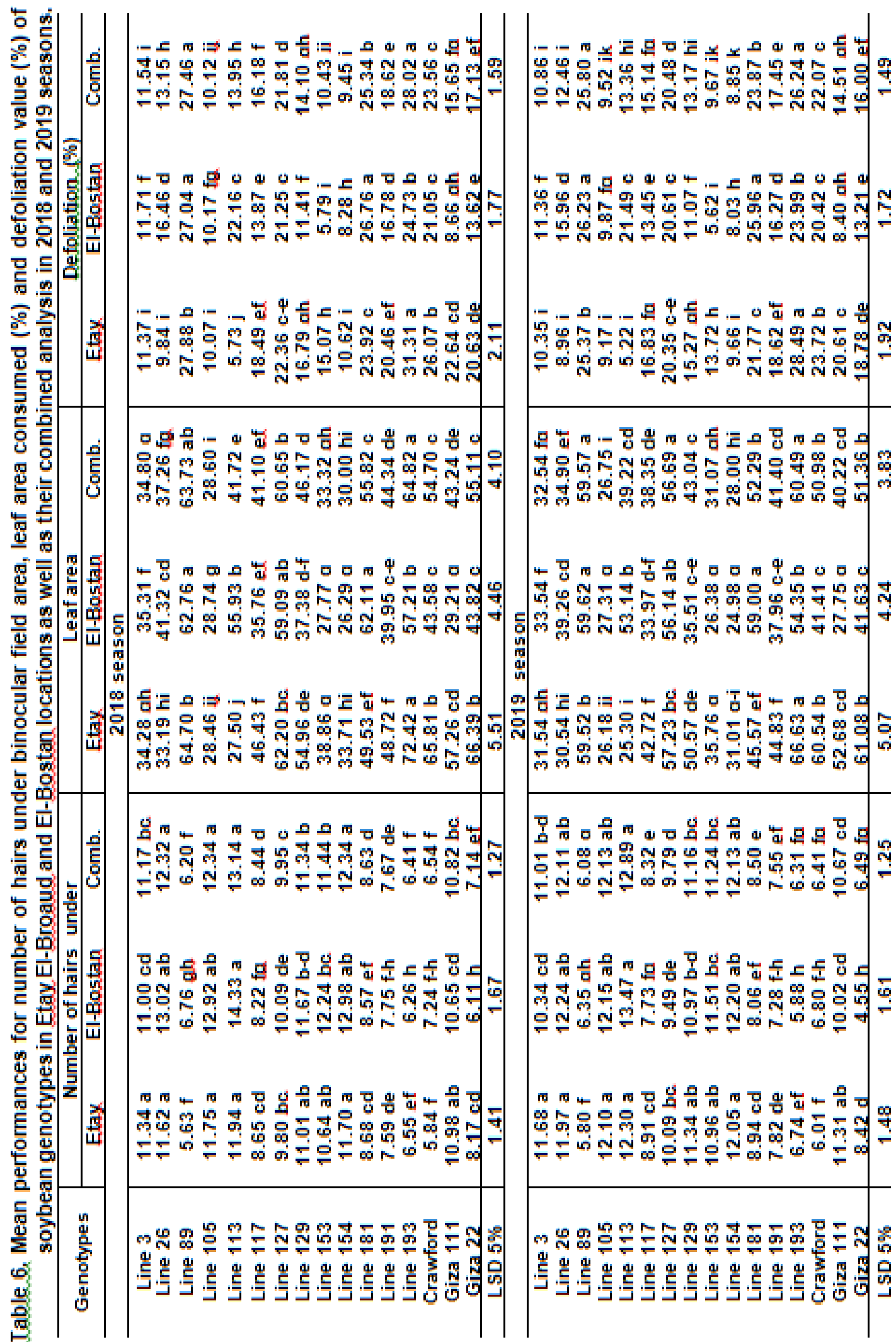


For leaf area consumed, Line 3, Line 26, Line 105, Line 113, Line 129 and Line 154 showed excellent resistance to cotton leaf worm under the lab conditions in both seasons. Line 105 was the most

resistance genotype to cotton leaf worm where it showed the lowest leaf area consumed in Etay El-Baroud (28.46 and $26.18 \%$ ) and in El-Bostan (28.74 and 26.31 $\%)$ as well as the combined data $\mathbf{2 8 . 6 0}$ and $26.75 \%$ in both seasons, respectively followed by Line 154 with averages of 33.71 and $31.01 \%$ in Etay ElBaroud, 26.29 and $24.98 \%$ in El-Bostan and 30.00 and $26.75 \%$ in the combined data in the first and second seasons, respectively. On the other side, Line 89 and Line 193 were the most susceptible genotypes to cotton leaf worm in both seasons where the two lines recorded the highest leaf area consumed across the two locations in both seasons.

With respect to defoliation values under the field conditions, Line 3 , Line 26, Line 105, Line 153 and Line 154 showed excellent resistance to cotton leaf worm under the field conditions in both seasons. Line 154 was the most resistance genotype to cotton leaf worm where it showed the lowest defoliation values in Etay El-Baroud (10.62 and 9.66\%) and in El-Bostan (5.79 and $8.03 \%$ ) as well as the combined data 9.45 and $8.85 \%$ ) in both seasons, respectively followed by Line 105 with averages of 10.07 and $9.17 \%$ in Etay El-Baroud, 10.17 and $9.87 \%$ in El-Bostan and 10.12 and $9.52 \%$ in the combined data in the first and second seasons, respectively. On the other side, Line 89 and Line 193 were the most susceptible genotypes to cotton leaf worm in both seasons where the two lines recorded the highest defoliation values in the field conditions across the two locations in both seasons.

\subsection{Growth traits.}

It was evident that the behavior of all tested genotypes varied across the two sowing locations, as the results showed a remarkable early in maturation of all genotypes in El-Bostan location, with clear dwarft of plant height accompanied by a slight decrease in the number of branches compared to plants that sowing in Etay El-Baroud (Table 7).

Mean performances of all tested genotypes for maturity date (days), plant height $(\mathrm{cm})$, and number of branches/plant in the two locations as well as the combined data are demonstrated in Table 7. maturity date the results cleared that the four genotypes Line 113, Line 127, Line 181 and Crawford were the earliest among all tested genotypes in both Etay ElBaroud and El-Bostan locations as well as the combined data in both seasons. among these genotypes Line 127 was the earliest one where it expressed the lowest number of days maturity in Etay El-Baroud (108.11 and 97.33 days) and in El-Bostan (107.3 and 96.36 days) as well as in the combined data (107.57 and 96.85 days) in both seasons, respectively. In contrast this Line 129 and Line 193 were the latest among all tested genotypes in both locations and the combined data in the two seasons of the study.

Regarding plant height, Line 3 and Line 105 were the tallest among all tested genotypes in both seasons. Line 3 showed the highest plant height in Etay El-Baroud $(112.58$ and $117.09 \mathrm{~cm}$ ) and in El-Bostan $(111.46$ and $119.26 \mathrm{~cm})$ as well as the combined data (112.02 and 118.18 $\mathrm{cm}$ ) in both seasons, respectively followed by Line 105 with averages of 103. 65 and $107.80 \mathrm{~cm}$ in Etay El-Baroud, 100.54 and $107.58 \mathrm{~cm}$ in El-Bostan, and 102.10 and $107.69 \mathrm{~cm}$ in the combined data in the first and second seasons, respectively. On the other hand, Line 89 


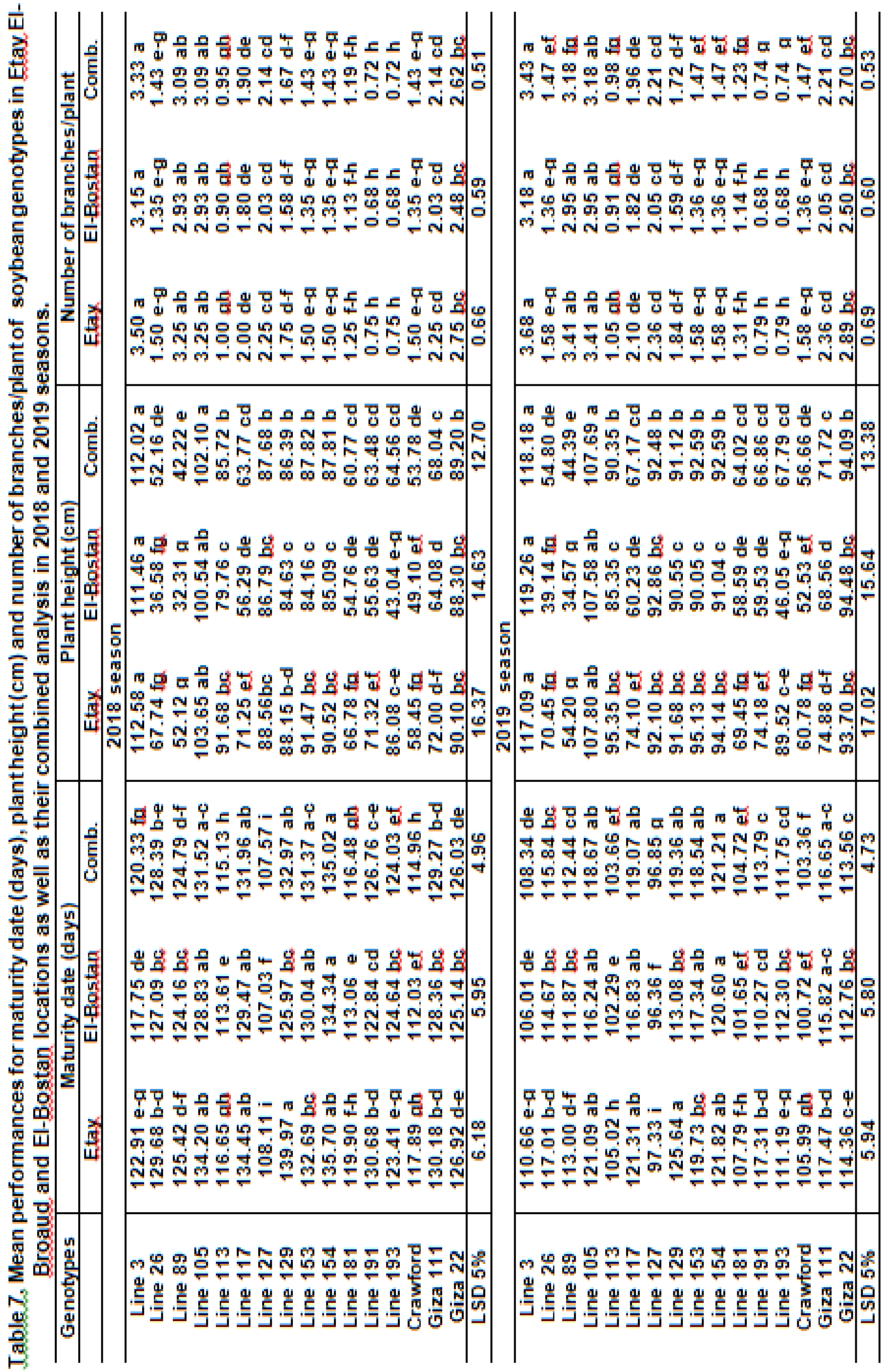


and Line $\mathbf{2 6}$ were the shortest among all tested genotypes in both seasons.

For number of branches/plant, Line 3, Line 89 and Line 105 gave the highest branches number/plant among all tested genotypes in both seasons. The highest number of branches in these three genotypes were presented in Line 3 in Etay El-Baroud (3.50 and 3.68) and in El-

Bostan (3.15 and 3.18) as well as the combined data (3.33 and 3.43) in both seasons, respectively followed by Line 105 and Line 89 with the same averages 3.25 and 3.41 in Etay El-Baroud, 2.93 and 2.95 in El-Bostan and 3.09 and 3.18 in the combined data in the first and second seasons, respectively. On the other side, Line 191 and Line 193 showed the lowest number of branches/plant among all tested genotypes across the two locations and the combined data in both seasons.

\subsection{Seed yield and yield component traits.}

The data in Table 8 cleared that all yield and yield component traits sharply decreased in El-Bostant locations except 100-seed weight compared to Etay ElBaroud.

For number of pods/plant, the results confirmed that the four genotypes Line 3, Line 129, Giza 1111 and Giza 22 expressed the highest number of pods/plant among all tested genotypes in both Etay El-Baroud and El-Bostan locations in both seasons as well as the combined data in the second season. Among these genotypes Line 129 had the highest number of pods/plant in Etay ElBaroud (81.92 and 90.12) and in ElBostan (47.19 and 69.21) in both seasons, respectively as well as in the combined data (79.67) in the second season. In contrast, Line 26, Line 89, and Line 193 showed the lowest pods number/plant among all tested genotypes in both locations and the combined data in the two seasons of the study.

For 100-seed weight Line 105 and Line 181 showed the heaviest 100 -seed weight among all tested genotypes across the two locations in both seasons. Line 105 showed the highest 100-seed weight in Etay El-Baroud (16.62 and $15.29 \mathrm{~g}$ ) and in El-Bostan (18.78 and $17.28 \mathrm{~g}$ ) as well as the combined data (17.70 and $16.29 \mathrm{~g}$ ) in both seasons, respectively. On the other side, Line 129 gave the lowest 100 -seed weight among all tested genotypes across the two locations in both seasons.

Regarding to seed yield/plot, the five genotypes Line 3, Line 105, Line 127, Line 129 and Giza 22 gave the highest seed yield/plot in the two locations among all tested genotypes in both seasons. The highest seed yield/plot in these three genotypes were presented in Line 3 in Etay El-Baroud (6.41 and 6.71 $\mathrm{kg})$ and in El-Bostan (3.17 and $4.87 \mathrm{~kg}$ ) in both seasons, respectively. On the other side, Line 26 showed the lowest seed yield/plot among all tested genotypes across the two locations in both seasons.

With regard to seed yield/Fad, the four genotypes Line 3, Line 105, Line 127 and Giza 22 gave the highest seed yield/fad in the two locations among all tested genotypes in both seasons. The highest seed yield/fad in these three genotypes were presented in Line 3 in Etay ElBaroud (2243.36 and $2348.99 \mathrm{~kg})$ and in El-Bostan (1110.46 and $1703.93 \mathrm{~kg}$ ) in both seasons, respectively. On the other side, Line 26 showed the lowest seed yield/fad among all tested genotypes across the two locations in both seasons.

For seed content of oil, the two genotypes Line 129 and Line 181 had the highest seed content of oil in the two locations and their combined data among all tested genotypes in both seasons. The highest seed content of oil in these 


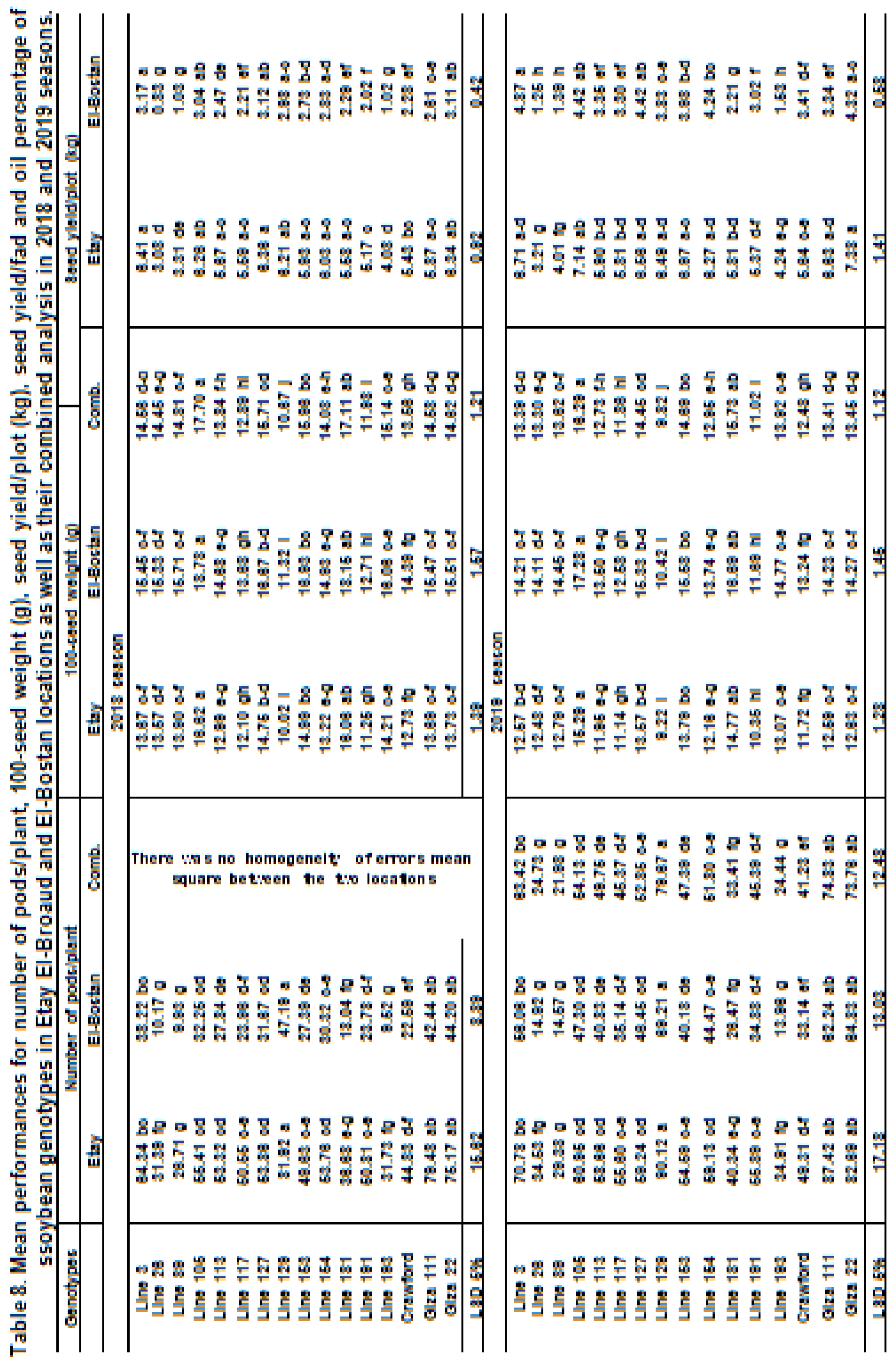




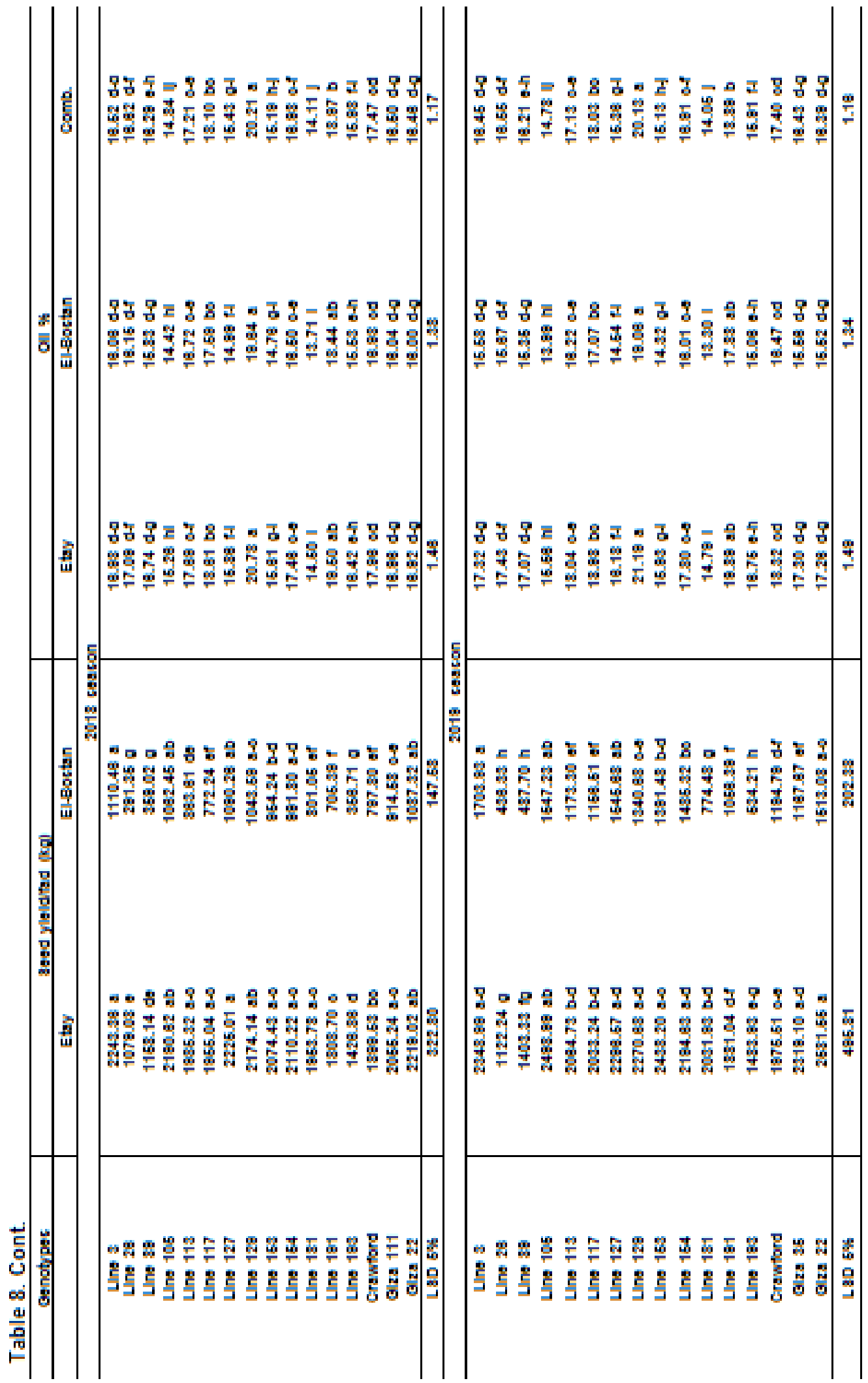


genotypes was presented in Line 129 in Italy El-Baroud (20.78 and $21.19 \%)$ and in El-Bostan (19.64 and 19.06\%) as well as the combined data (20.21 and $20.13 \%$ ) in both seasons, respectively. On the other side, Line 181 showed the lowest seed content of oil among all tested genotypes across the two locations and their combined data in both seasons.

3. The relationship between Pubescence density and both leaf area consumed and defoliation \% caused by the cotton leaf worm in the laboratory and the field

Figure 2 illustrates the relationship between soybean leaf consumed area caused by cotton leaf worm in the field and in the laboratory with the Pubescence density on soybean leaf surface. From this relationship it can be seen that the correlation of the consumed areas of soybean leaves in the lab and field was negatively associated with the Pubescence density with regression coefficients of 0.24 and 0.50 for leaf area consumed and defoliation values $\%$ in the lab and the field, respectively. This means that with the increase in the Pubescence density on the soybean leaves, the consumed areas by the cotton leaf worm are reduced, as these hairs impede the insect's access to the leaf surface, preventing it from feeding on the leaves.

\section{The relationship between Pubescence density and both seed yield/fad and oil\% in soybean seeds.}

The relationship between seed yield and oil percentage of soybean with the Pubescence density on soybean leaf surface are shown in Fig. 3. From this relationship it can be clear that the correlation of the seed yield and Pubescence density was insignificant positive $\left(R^{2}=0.29\right)$ while, oil percentage insignificant negative associated with Pubescence density with regression coefficients of 0.004 . This means that with the increase in the Pubescence density on the soybean leaves, seed yield will increase and oil percentage will decrease.

\section{The relationship between defoliation values of soybean leaves caused by cotton leaf worm and both seed yield/fad and oil\% in soybean seeds.}

The relationship between seed yield and oil percentage of soybean with the defoliation value caused by cotton leaf worm are shown in Fig. 4. From this relationship it could be detect that the correlation of the seed yield with defoliation values was insignificant negative $\left(R^{2}=0.31\right)$ also, oil percentage insignificant negative associated with defoliation values with regression coefficients of 0.02 . This means that with the increase in the defoliation values on the soybean leaves, seed yield and oil percentage will decrease. Under the high infections with cotton leaf worm a high stress in soybean plants were happened and this may resulted in a large decrease in assimilation in the plant and this caused a large decrease in dry matter therefor seed yield and oil percentage will decreased. 


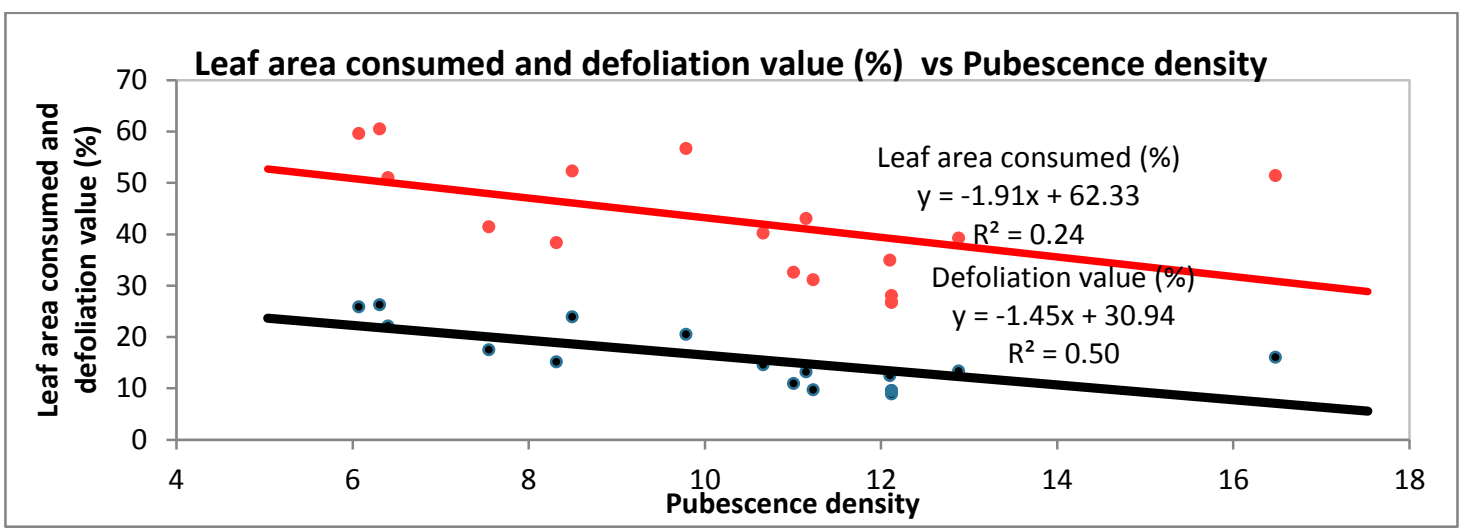

Fig. 2. The relationship between Pubescence density and both leaf area consumed and defoliation \% caused by the cotton leaf worm in the laboratory and the field.
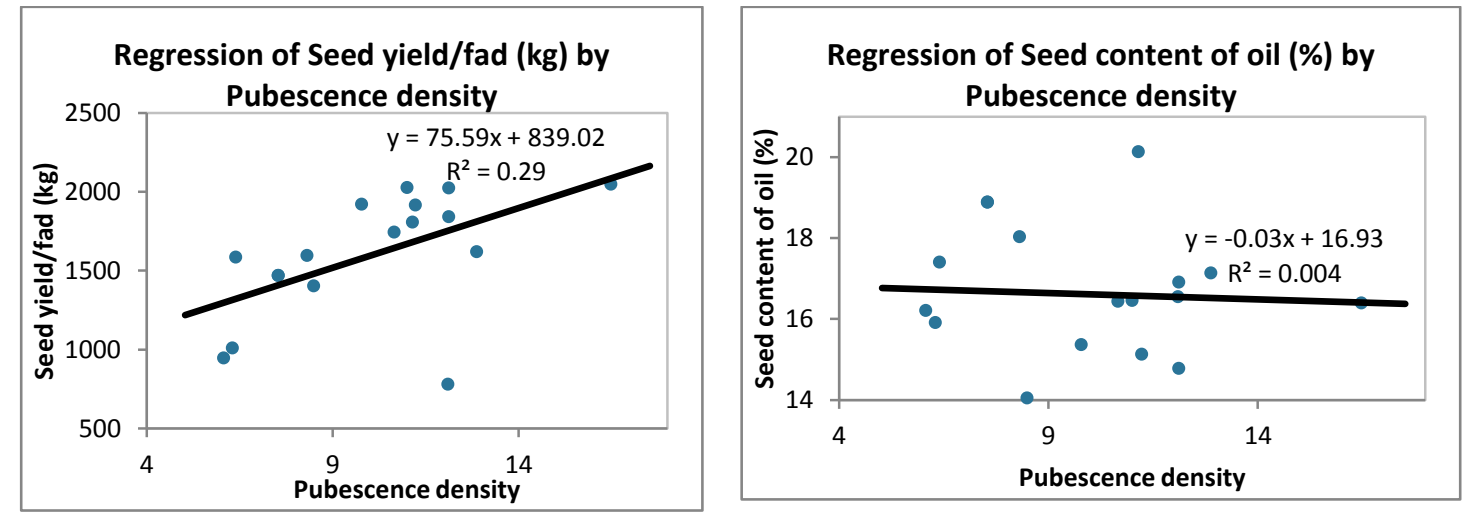

Fig. 3. The relationship between pubescence density and both seed yield/fad and oil percentage of soybean.
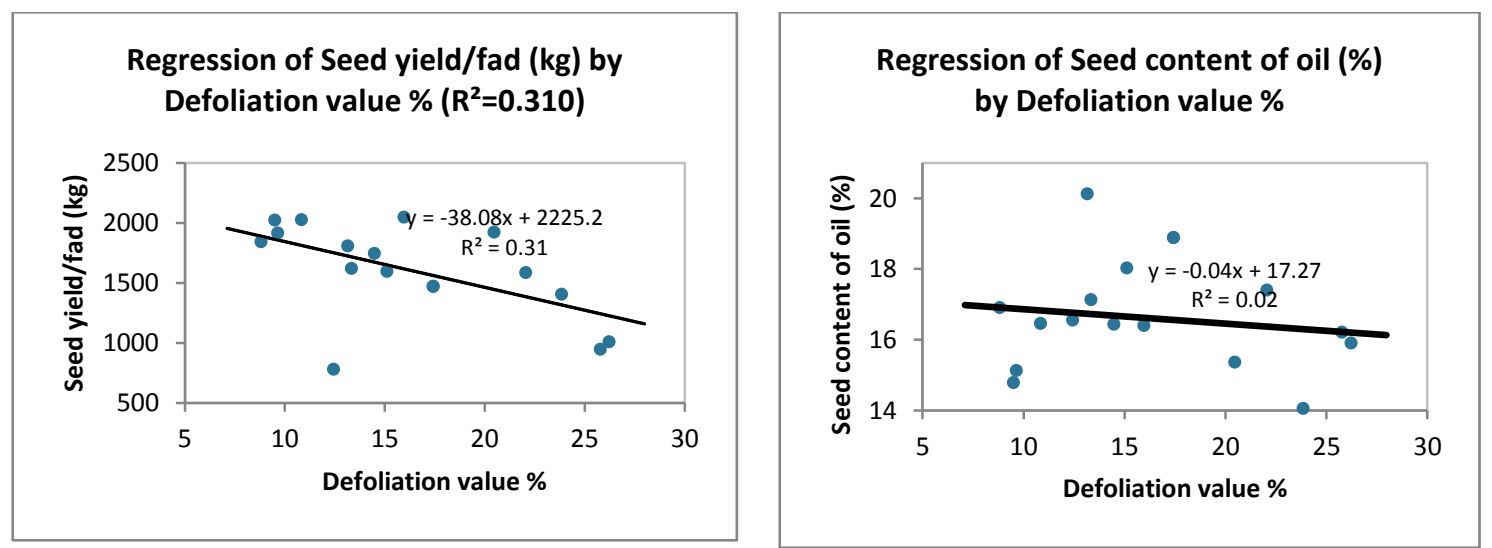

Fig 4. The relationship between defoliation values of soybean leaves caused by cotton leaf worm and both seed yield/fad and oil percentage of soybean seeds.

\section{DISCUSSIONS}

\section{Mean squares:}

In this study mean square due to genotypes, locations and genotypes $x$ location were highly significant for all studied traits except the locations mean square for number of hairs under binocular field area and branches 
number /plant in the first season and genotypes $x$ location mean square of number of hairs under binocular field area, branches number /plant, maturity date and 100-seed weight in both seasons as well as number of pods/plant in the second season. Genotypes mean square significant confirmed the wide genetic diversity between genotypes and these genotypes will differ in their performances. Also, Gurmu et al., (2009) found highly significant $\quad(P<0.01)$ environment, genotype and GEI effects, mean squares, which confirmed the influence of both genotypes and environments in soybean genotypes.

The significant of mean square due to locations indicated that all genotypes will influence by the site of sowing. The significance of $G \times E$ interactions for these traits confirms the variation in the performance of genotypes in different environments. Thus, the large differences between environments along with the stability of the genetic response are important for selecting genotypes with high stability in different environments (Dillion et al., 2009 and Jai Dev et al., 2009).

\section{Mean performances:}

Our findings confirmed that all tested genotypes significantly differ in their performances in all studied traits across the two locations and the four lines Line 3, line 105, line 127 and line 129 seemed to excellent genotypes for yield and resistance to cotton leaf worm across the two locations. The diversity between soybean genotypes were observed before in some studies such as Krisnawati and Adie (2018) evaluated the stability of 12 soybean genotypes of soybean mega-environments for the yield performance. They revealed that yield and yield components of soybean genotypes were highly influenced by genotype $x$ environment interaction except branch number/plant. Genotypes 8 and 2 were the best yielding genotypes in the most discriminating environment, but adapted to specific environment, thus highly recommended for that specifc location. Genotypes 9 and 10 were stable and had relatively high yield performances across environments. Attia (2014) evaluated ten soybean genotypes and he found that the best genotype Etay El-Baroud05 was at the first rank showing highest density of pubescence as physical characteristic and lowest rate of defoliation \%, also had highest considering resist effect against insect attack. ETAY EL-BAROUD05 had more branches and bearing larger number of pods /plant could increase seed yield /plant (g) and 100-seed weight (g). Giza 22 was at the last rank with negative effect for earliness characters and high percentage of defoliation.

The relationships between resistance to cotton leaf worm, seed yield and oil percentage traits.

In this study the consumed leaf area caused by cotton leaf worm and oil percentage negatively associated with pubescence density while seed yield positively associated with pubescence density. Similar results were obtained before by, Gunasinghe et al., (1988) found a large decrease in Aphis citricola activity under the high density of soybean leaf pubescence. Hill et al., (2004) studied the effect of soybean pubescence on insect pests, such as reduced damage due to feeding by plant hoppers and they found that the higher pubescence density the higher resistance to defoliation and reduced feeding leaf damage. Sridhar and Siddiqui (2009) studied the morphological features in five soybean cultivars, revealed that leaf area and trichome density on abaxial leaf surface were positively associated with the 
resistance. In resistant varieties, leaf petioles were with lower moisture content as compared to susceptible varieties. Attia (2014) reported that, yield production was clearly affected by increasing pubescence density as well as defoliation $\%$ rate. He found that the genotype Etay El-Baroud05 was at the first rank showing highest density of pubescence as physical characteristic and lowest rate of defoliation \%, also had highest considering resist effect against insect attack. Nautiyal et al., (2015) reported a highly significant negative correlation between leaf hair density and per cent infestation for S.obliqua, $S$. litura. Sasane et al., (2018) reported that pubescence density has significantly negative correlation with incidence of Spodoptera larvae $(r=-.459,-0.463)$ at 25 and 40DAS.

Our findings revealed that, seed yield and oil percentage negatively associated with the defoliation value. In the previous Miranda et al., (2003) reported that the cultivars showing lowest defoliation by caterpillars has good yield and should be recommended for cultivation. Attia (2014) reported that, yield production was clearly affected defoliation $\%$ rate.

\section{REFERENCES}

Ademir, D.N., R.F. Oliveira and J.R.P. Parra (2006). A new concept for insect damage evaluation based on plant physiological variables. Anais da Academia Brasileira de Ciências,78 (4): 821- 835.

Attia, S.A.A. (2014). Correlation coefficient analysis for quantitative and resistance characters with fingerprinting in ten soybeans (Glycine max (I.)) Genotypes based on DNA polymorphism. Middle East Journal of Applied Sciences, 4(2): 318325

Baker, R.J. (1988). Tests for crossover genotype $x$ environment interactions.
Can. J. Plant Sci. 68:405-410.

Cochran, W.G. and G.M. Cox (1957). Experimental Design. 2nd Edition, John Wiley and Sons, New York, 615 p.

Dhillion, S. K., G. Singh, B. S. Gill and P. Singh (2009). Stability analysis for grain yield and its components in soybean (Glycine max. L. Merrill). Crop Improvement, 36(1): 55-58.

El-Agroudy, N., S. Mokhtar, E.A. Zaghlol and M. El-Gebaly (2011). An economic study of the production of soybean in Egypt. Agriculture and biology journal of North America. 2(2):221-225.

FAOSTAT (2019). Food and Agriculture Organization of the United Nations, FAOSTAT Agriculture Data. http://www.fao.org/faost at/en/\#data/QC (accessed August 21, 2019.

Gomez, K.A. and A.A. Gomez (1984). Statistical procedures for Agricultural Research. ( $\left.2^{\text {nd }} \mathrm{ed}\right)$. An International Rice Research Institute J. Wiley and Sons, New York, USA. pp. 377-434.

Gunasinghe, U. B., M. E. Irwin and G. E. Kampmeier (1988). Soybean leaf pubescence affects aphid vector transmission and field spread of soybean mosaic virus. Annals of Applied Biology, 112 (2): 259-272

Gurmu, F., H. Mohammed and G. Alemaw (2009). Genotype X environment interactions and stability of soybean for grain yield and nutrition quality. African Crop Science Journal, Vol. 17, No. 2, pp. 87 - 99.

Hill, C. B., Y. Li and G. L. Hartman (2004). Resistance to the Soybean Aphid in Soybean Germplasm. Crop Science, Vol. 44, JanuaryFebruary 2004.

Jai Dev., D. Anand, V. Kumari, V. K. Sood, A. Singh, A. Singh, R. P. Kaushal, J. K. 
Jenjiha and O. P. Sood (2009). Genotype $x$ environment interaction for yield and maturity in soybean. Crop Improvement, 36(1): 59-63.

Jain H. and M. Kharkwal (2003). Plant breeding. New Delhi, Narosa Publishing House Pvt. Ltd.

Kang, M.S. (1998). Using genotype-byenvironment interaction for crop cultivar development.

Adv. Agron., 35:199-240.

Krisnawati A. and M. M. Adie (2018). Genotype by environment interaction and yield stability of soybean genotypes. Indonesian J. Agric. Sci. 19 (1): 25-32

Kumar, A., S. Kumar, C. Kapoor, R. Bhagawati, A. Pandey and A. Pattnayak (2014). GGE biplot analysis of genotypex environment interaction in soybean grown in NEH regions of India. Environment \& Ecology. 32 (3A), 1047-1050

Kuswantoro, H. (2016). Potential yield of acid-adaptive soybean promising lines in Ultisols of Tanah Laut Regency, South Kalimantan Province, Indonesia. Biotropia. [Online] 23 (1), 52-57.

Miranda, M.A.C., N.R. de, Braga, A.L. Lourencao, F.T.S. Miranda, S.H. de, Uneda and M.F. Ito (2003). Description, yield and stability of early soybean insect resistant cultivar IAC23Bragantia.; 62(1): 19-27.

Nautiyal, A., N. Gaur and P. Sharma (2015). Morphological parameters of soybean plant resistance to lepidopterous defoliators. Journal of Hill Agriculture. 2015; 6(1): 89-92.

Sasane, A.R., S.K. Bhalkare, P.K. Rathod and D.B. Undirwade (2018). Biophysical basis of resistance in soybean genotypes against defoliators. Journal of Entomology and Zoology Studies 2018; 6(2): 01-07.

Smith, C. M., and C. A. Brim. (1979). Field and laboratory evaluations of soybean lines for resistance to com earwonn leaf feeding. J. Econ. Entomol. 72: 7880.

Soybean meal (2019). Retrieved April 16, 2019.

Sridhar, Y. and K.H. Siddiqui (2009). Morphological basis of resistance to stemfly Melanagromyza sojae in soybean. Indian Journal of Plant Protection. 2009; 37:78- 82.

Steel, R. C. D. and J. H. Torrie (1980). Reproduced from principles and procedures of statistics. Printed with the permission of C. I. Bliss, pp. 448449. 
تقييم المحصول و المقاومة لاودة ورق القطن لبعض التراكيب الوراثية الجديدة من فول الصويا تحت ظروف الأراضى القديمة و الأراضى حديثة الإستصلاح بمحافظة البحيرة

$$
\text { فايز السيا والىى }
$$

قسم بحوث المحاصيل البقولية- معهل بحوث المحاصيل الحقلية- مركز البحوث الزراعية- الجيزة-مصر

الملخص العربى

تم إجراء تجرية حقلية فى قطاعت كاملة العشوائية من ثلاث مكررات فى المزرعة البحثية لمحطة البحوث الزراعية

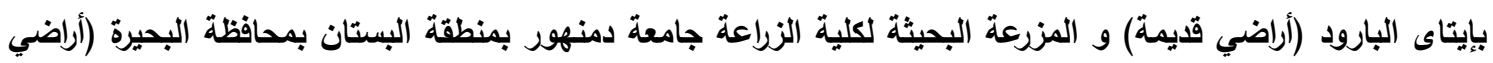

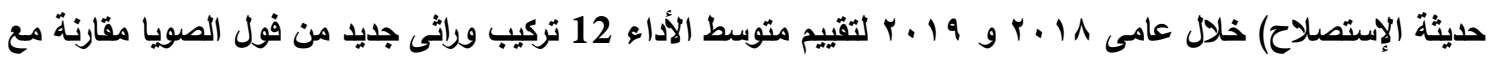

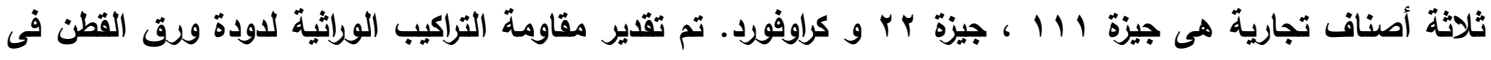

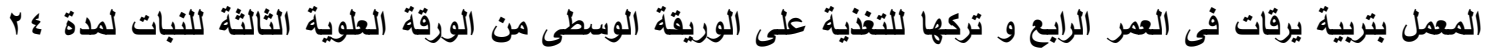
ساعة بعد ذلك تم قياس المساحات التى قامت الحشرة بالتغذية عليها كنسبة مئوية من مساحة الورقة الكلية (المساحة

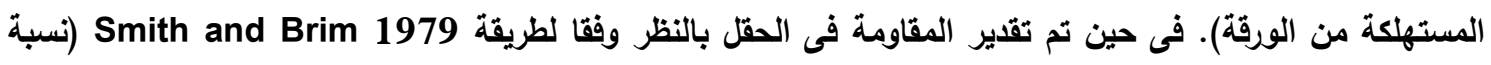

وقد اظهرث النتائج أن ان التباين الراجع إلى التراكيب الوراثية والمواقع والتفاعل بين التراكيب × الموقع كان عالى التي

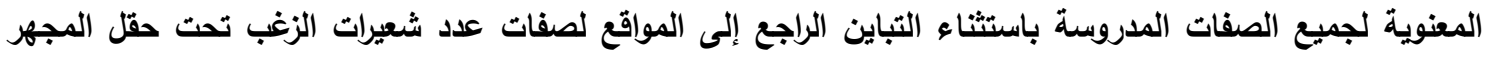

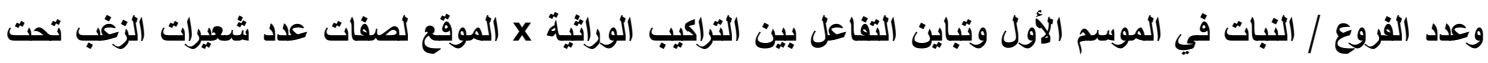

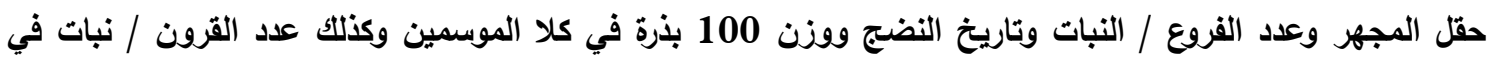
أظهرت جميع التراكيب الوراثية المختبرة اختلافًا كبيرًا في متوسطات الأداء في جميع الصفات المدروسة فى كلا

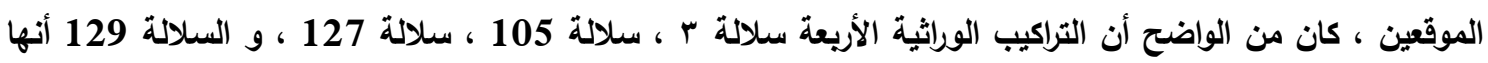
تراكيب وراثية ممتازة للمحصول ومقاومة دودة أولق القطن في كلا الموقعين.

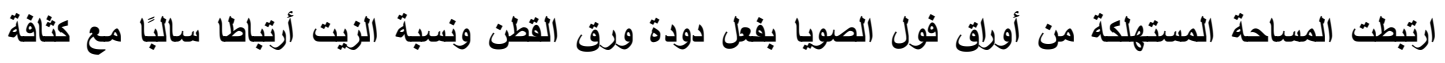
شعيرات الزغب على سطح الاولق بينما ارتبط محصول البذرة بثكل إيجابي بكثافة الزغب.

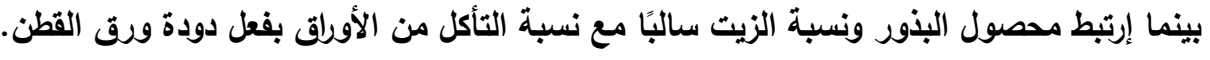

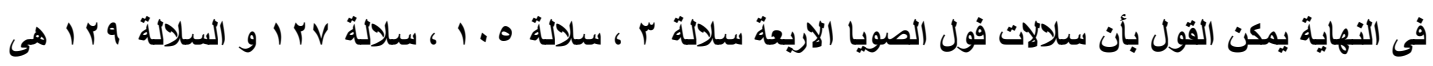

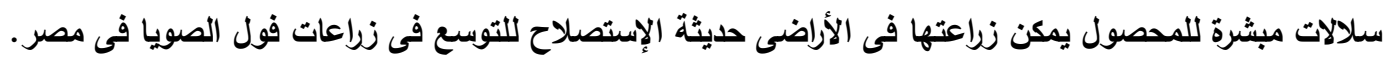


أ.د/ حسان عبد الجيد دوام كلية الزراعة - جامعة المنوفية 